\title{
PENGARUH VITAMIN B 6 DALAM PAKAN TERHADAP SISTEM KEKEBALAN BENIH IKAN KERAPU BEBEK, Cromileptes altivelis
}

\author{
Fris Johnny, Nyoman Adiasmara Giri, Ketut Suwirya, dan Des Roza
}

\begin{abstract}
ABSTRAK
Percobaan pemberian vitamin $\mathrm{B}_{6}$ dalam pakan ikan telah dilakukan di laboratorium patologi Balai Besar Riset Perikanan Budidaya Laut, Gondol-Bali. Tujuan percobaan ini adalah untuk mengetahui pengaruh vitamin $B_{6}$ dengan dosis yang berbeda dalam pakan ikan terhadap sistem kekebalan benih ikan kerapu bebek. Benih ikan kerapu bebek. Cromileptes altivelis sebanyak 180 ekor dengan bobot awal antara 10-20 g disebar secara acak ke dalam 18 buah bak fiber volume $100 \mathrm{~L}$ dengan sistem air laut mengalir dan diaerasi. Ikan diberi pakan berupa pelet kering dengan dosis vitamin $B_{6}$ berbeda, yaitu $0 \mathrm{mg}$ (sebagai kontrol), $2 \mathrm{mg}, 4 \mathrm{mg}, 6 \mathrm{mg}, 8 \mathrm{mg}$, dan 16 $\mathrm{mg}$ vitamin $\mathrm{B}_{6}$ dalam $100 \mathrm{~g}$ pakan. Pakan diberikan dua kali sehari, pagi dan sore hari. Percobaan dirancang menggunakan rancangan acak lengkap dengan tiga ulangan. Pengamatan parameter sistem kekebalan ikan uji dilakukan setelah 18 minggu terhadap aktivitas fagositik (PA), indeks fagositik (PI), dan aktivitas lisosim (LA). Hasil percobaan menunjukkan bahwa penambahan vitamin $B_{6}$ dalam pakan ternyata sangat mempengaruhi PA dan $L A$ benih ikan kerapu bebek $(P<0,05)$. Nilai $P A$ dan $L A$ tertinggi diperoleh pada perlakuan vitamin $B_{6} 6 \mathrm{mg} / 100 \mathrm{~g}$ pakan. Perlakuan vitamin $\mathrm{B}_{6}$ dalam pakan ikan dapat memacu sistem kekebalan benih ikan kerapu bebek.
\end{abstract}

\section{ABSTRACT: The effects of vitamin $B_{6}$ on the immune system of humpback grouper juveniles, Cromileptes altivelis. By: Fris Johnny, Nyoman Adiasmara Giri, Ketut Suwirya, and Des Roza}

An experiment on the effects of vitamin $B_{6}$ on the immune system as non-specific immune response of humpback grouper, Cromileptes altivelis juveniles had been conducted at the Pathology Laboratory of the Gondol Research Institute for Mariculture, Bali. Six groups of fish, 30 fish each, with body weight ranged from 10 to $20 \mathrm{~g}$ were maintained on diet supplemented with different concentrations of vitamin $B_{6^{\prime}}$ namely $0 \mathrm{mg}, 2 \mathrm{mg}, 4 \mathrm{mg}, 6 \mathrm{mg}, 8 \mathrm{mg}$, and $16 \mathrm{mg} / 100 \mathrm{~g}$ of diet respectively. The parameters of non-specific immune response changes observed were phagocytic activity (PA), phagocytic index (PI), and lysozyme activity (LA). Data were collected after 18 weeks of the experiment. Results showed the vitamin $B_{6}$ on diet stimulated non-specific immune response as $P A$ and $L A$ humpback grouper juvenile $(P<0.05)$. The highest value of PA and $L A$ was obtained on the treatment with vitamin $B_{6} 6 \mathrm{mg} / 100 \mathrm{~g}$ diet. Vitamin $B_{6}$ treatment was able to stimulate the immune response of humpback grouper juvenile.

KEYWORDS: $\quad$ vitamin $B_{6}$, immune system, humpback grouper juvenile

\section{PENDAHULUAN}

Sel darah, terutama leukosit atau sel darah putih, mempunyai peran sangat penting dalam sistem kekebalan. Leukosit mempunyai beberapa jenis dan fungsi dalam melawan benda asing yang berhasil masuk ke dalam tubuh hewan. Kemampuan leukosit dapat ditingkatkan dengan menggunakan imunostimulan, vitamin, dan hormon (Anderson, 1974; Manning \& Tatner, 1985; Post, 1987; Schubert, 1987; Andrew et al., 1988; Tizard, 1988; Brown, 1993; Stoskopf, 1993; Klontz, 1994; Anderson, 1996).

Penggunaan imunostimulan akhir-akhir ini sudah banyak dilakukan, menyusul banyaknya kasus penyakit yang tidak efektif ditanggulangi dengan obat konvensional (Rukyani et al., 1999). Penambahan unsur atau bahan yang dapat memacu timbulnya ketahanan tubuh seperti vitamin $\mathrm{C}$ dan $\mathrm{E}$ merupakan alternatif baru dalam penanggulangan penyakit ikan.

Pengaruh vitamin $\mathrm{B}_{6}$ terhadap darah ikan telah dilaporkan oleh Wanakowat et al. (1989) pada ikan kakap, Lates calcarifer, pada ikan mas Cyprinus carpio (Sakthivel \& Sampath, 1989), pada ikan nila, Oreochromis niloticus (Shiau \& Hsieh, 1997), dan pada ikan kerapu bebek, Cromileptes altivelis (Johnny et al., 2004). Sedangkan pengaruh kombinasi vitamin $\mathrm{C}$ dan glucan terhadap respon imun non spesifik baru dilaporkan oleh Verlhac et al. (1998) pada ikan rainbow trout, Oncorrhynchus mykiss. Wahli et al. (1998) menggunakan kombinasi vitamin $\mathrm{C}$ dan $\mathrm{E}$ pada jenis

Peneliti pada Balai Besar Riset Perikanan Budidaya Laut, Gondol 
ikan yang sama. Pada ikan lele dumbo, Clarias sp. pemberian vitamin C dalam pakan dapat meningkatkan respon imun non spesifik (Rukyani et al., 1999). Selanjutnya Johnny et al. (2003) melaporkan pula bahwa pemberian vitamin $\mathrm{C}$ dalam pakan benih ikan kerapu macan, Epinephelus fuscoguttatus berpengaruh terhadap keragaan respon imun non spesifik.

Vitamin $B_{6}$ terdiri atas tiga derivat piridin yang berhubungan erat yaitu; piridoksin, piridoksal, dan piridoksamin (turunan vitamin $\mathrm{B}_{12}$ ), dan derivat fosfat yang bersesuaian. Dari semua derivat ini, piridoksin, piridoksal, piridoksamin, dan piridoksamin fosfat merupakan wakil utama vitamin tersebut dalam makanan. Ketiga bentuk di atas semuanya memiliki aktivitas vitamin yang sama karena dapat melakukan inter konversi satu sama lain di dalam tubuh. Semua bentuk vitamin tersebut diabsorbsi dari dalam intestin, tetapi hidrolisis senyawa ester fosfat tertentu terjadi selama proses pencernaan (Murray et al., 1997). Defisiensi vitamin $\mathrm{B}_{6}$ dapat menyebabkan anemia. Anemia terjadi akibat terganggunya sintesis DNA yang menghalangi pembelahan sel dan pembentukan nukleus pada eritrosit yang baru dengan penumpukan megaloblas dalam organ pembentukan eritrosit. Wanakowat et al. (1989) melaporkan bahwa yuwana kakap, Lates calcarifer tanpa pemberian vitamin $\mathrm{B}_{6}$ setelah 2-6 minggu memperlihatkan gejala klinis anoreksia, pertumbuhan terhambat, berenang di permukaan, lesi pada bagian bawah bibir, kejang, dan tingkat kematian yang tinggi.

Percobaan ini bertujuan untuk mengetahui pengaruh penambahan vitamin $B_{6}$ dalam pakan dengan perbedaan dosis terhadap keragaan parameter sistem kekebalan benih ikan kerapu bebek yaitu aktivitas fagositik (PA), indeks fagositik (PI), dan aktivitas lisosim (LA).

\section{BAHAN DAN METODE}

\section{Pakan Uji}

Komposisi pakan uji yang digunakan dalam percobaan ini adalah seperti disajikan pada Tabel 1 , dengan pakan uji yang digunakan sebanyak 6 perlakuan yaitu pelet yang berisikan nutrisi esensial dan vitamin $B_{6}$ dengan 6 dosis berbeda. Perlakuan $A$ tanpa vitamin $B_{6}$ sebagai kontrol, dan perlakuan $B, C$, $D, E$, dan $F$ masing-masing dengan dosis $2,4,6,8$, dan $16 \mathrm{mg}$ vitamin $\mathrm{B}_{6} / 100 \mathrm{~g}$ pakan pelet. Vitamin $\mathrm{B}_{6}$ yang digunakan adalah piridoksin, secara rinci dosis vitamin $\mathrm{B}_{6}$ dalam pakan ditampilkan pada Tabel 1

\section{Ikan Uji}

Ikan uji yang digunakan adalah benih ikan kerapu bebek, Cromileptes altivelis dengan bobot awal antara $10-20 \mathrm{~g}$ yang telah diaklimatisasi pada kondisi percobaan selama 7 hari. Bak uji yang digunakan adalah bak fiber kapasitas $100 \mathrm{~L}$ sebanyak 18 buah dengan sistem air laut mengalir dan diaerasi. Setiap bak berisikan masing-masing 10 ekor ikan uji. Ikan uji diberi pakan dua kali sehari dengan dosis $3 \%$ $5 \%$ bobot badan dan lama percobaan selama 18 minggu.

Percobaan ini menggunakan rancangan acak lengkap dengan tiga ulangan dan data dianalisis dengan ANOVA. Peubah yang diamati adalah aktivitas fagositik (PA), indeks fagositik (PI), dan aktivitas lisosim (LA).

\section{Koleksi darah dan pemisahan leukosit}

Darah ikan uji diambil dari vena jugularis setelah terlebih dahulu ikan uji dipingsankan dengan menggunakan bahan pembius $F A-100$ produksi Tanabe

Tabel 1. Komposisi pakan uji (100 g pakan)

Table 1. Composition of test diet (100 g diet)

\begin{tabular}{lcccccc}
\hline \multicolumn{1}{c}{ Bahan (Ingredient) } & A & B & C & D & E & F \\
\hline Tepung ikan (Fish meal) & 50 & 50 & 50 & 50 & 50 & 50 \\
Kasein (Casein) & 20 & 20 & 20 & 20 & 20 & 20 \\
Lemak (Lipid) & 8 & 8 & 8 & 8 & 8 & 8 \\
Dekstrin (Dextrin) & 16 & 16 & 16 & 16 & 16 & 16 \\
Campuran vit (Vit. Mix) (Vit. B 6 ) & 1.3 & 1.3 & 1.3 & 1.3 & 1.3 & 1.3 \\
Campuran mineral (Mineral Mix.) & 1.7 & 1.7 & 1.7 & 1.7 & 1.7 & 1.7 \\
CMC & 2 & 2 & 2 & 2 & 2 & 2 \\
Sellulosa (Cellulosa) & 1 & 0.98 & 0.996 & 0.994 & 0.992 & 0.984 \\
Vit. B B $_{6}$ (Pindoxine) & 0 & 0.02 & 0.004 & 0.006 & 0.008 & 0.016 \\
\hline \multicolumn{1}{c}{ Total (100 g) } & 100 & 100 & 100 & 100 & 100 & 100 \\
\hline
\end{tabular}


Seiyaku, Jepang dengan dosis $1 \mathrm{cc} / 5 \mathrm{~L}$. Setelah ikan uji pingsan, sampel darah disedot dengan spuit plastik steril volume 2,5 cc dengan jarum No. 18 yang di dalamnya telah berisikan antikoagulan Heparin produksi Sigma. Selanjutnya disimpan dalam tabung evendoff.

Darah pada tabung evendoff disedot dengan tabung kapiler plastik, ditutup dengan lilin lebah dan disentrifusa pada kecepatan $12.000 \mathrm{rpm}$ selama 5 menit. Tabung kapiler dipotong dengan gunting pada batas leukosit dengan eritrosit, leukosit dikoleksi dan disimpan pada tabung evendoff baru, leukosit ini siap digunakan untuk uji fagositosis.

Sisa koleksi darah pada tabung evendoff disentrifusa dengan minisentrifusa dengan kecepatan $6.000 \mathrm{rpm}$ selama 5 menit, setelah disentrifusa plasma darah dipisahkan ke tabung evendoff baru dengan mikropipet, plasma ini siap digunakan untuk uji aktivitas lisosim. Metode yang digunakan adalah modifikasi dari metode Rowley (1993) dan Klontz (1994).

\section{Uji aktivitas fagositik (PA) dan indeks fagositik (PI)}

Untuk uji PA dan PI dibutuhkan bahan enzim Zymosan A (produksi Sigma) yang berasal dari Saccharomyces cerevisiae. Zymosan A diambil sebanyak $50 \mathrm{~mL}$ yang telah dilarutkan dengan larutan phosphate buffer saline (PBS), dimasukkan ke dalam tabung evendoff. Selanjutnya diambil leukosit yang telah disiapkan sebanyak $50 \mathrm{~mL}$ dan dicampurkan dengan Zymosan $\mathrm{A}$, diaduk rata dengan mikropipet, disimpan pada suhu $25^{\circ} \mathrm{C}$ selama 1 jam. Kemudian diteteskan pada kaca slide, dibuatkan preparat ulas tipis, dilakukan pewarnaan darah dengan May-Gruenwald's Solution Modified dan Gyemsa Solution 3\%, kemudian dihitung aktivitas fagositik (PA) dan indeks fagositik (PI) dilakukan berdasarkan rumus yang disajikan di bawah ini (Siwicki \& Anderson, 1993; Ellis, 1993).

$$
\begin{aligned}
\text { PA }(\%) & =\frac{\text { Fagositosis }}{\text { Total leukosit }} \times 100 \% \\
\mathrm{PI} & =\frac{\text { Jumlah zymosan A }}{\text { Jumlah fagosit }}
\end{aligned}
$$

\section{Uji aktivitas lisosim (LA)}

Sebelumnya disiapkan media agar yang mengandung Micrococcus lysodeikticus (produksi Sigma) pada cawan petri. Cawan petri yang berisikan media agar, dibuatkan lobang kecil sebanyak tiga lobang pada permukaan agar dengan menggunakan straw, masukkan sebanyak $10 \mathrm{~mL}$ plasma darah, dan pada lobang satunya dimasukkan chicken egg white lysozyme (produksi Sigma) sebagai kontrol. Didiamkan dulu selama 10 menit pada suhu kamar, kemudian disimpan pada inkubator dengan suhu $25^{\circ} \mathrm{C}$, dicek setiap hari dan diukur zona aktivitas lisosim (LA) dengan penggaris, pengamatan dilakukan selama 3 hari. Nilai LA dihitung dengan berdasarkan rumus tersaji di bawah ini menggunakan modifikasi dari metode Siwicki \& Anderson (1993) dan Ellis (1993).

$$
\mathrm{LA}(\mathrm{cm})=\frac{\text { Diameter plasma darah uji }}{\text { Diameter kontrol }}
$$

\section{HASIL DAN BAHASAN}

Data keragaan aktivitas fagositik (PA) dan indeks fagositik (PI) benih ikan kerapu bebek yang diberi pakan dengan dosis vitamin $\mathrm{B}_{6}$ berbeda disajikan secara lengkap pada Gambar 1

Dari Gambar 1 terlihat bahwa pengaruh vitamin $B_{6}$ terhadap keragaan aktivitas fagositik (PA) benih ikan kerapu bebek dosis $6 \mathrm{mg} / 100 \mathrm{~g}$ pakan (D) memberikan nilai PA tertinggi sebesar $10,08 \%$. Pada percobaan ini secara statistik perlakuan vitamin $B_{6}$ dibandingkan dengan kontrol berbeda nyata $(P<0,05)$. Nilai antar perlakuan dosis vitamin $B_{6}$ tidak berbeda nyata $(P>0,05)$. Dari percobaan ini terlihat bahwa perlakuan vitamin $B_{6}$ dengan peningkatan dosis memberikan nilai PA yang juga meningkat. Perlakuan vitamin $\mathrm{B}_{6}$ dosis $6 \mathrm{mg} / 100 \mathrm{~g}$ pakan memberikan nilai PAyang maksimal, namun menurun pada perlakuan vitamin $\mathrm{B}_{6}$ dosis $8 \mathrm{mg} / 100 \mathrm{~g}$ pakan. Johnny et al. (2004) melaporkan bahwa perlakuan vitamin $\mathrm{B}_{6}$ dalam pakan dapat meningkatkan jumlah eritrosit dan leukosit pada benih ikan kerapu bebek. Dengan meningkatnya jumlah total leukosit yang berfungsi sebagai sel fagosit, kemampuan fagositosisnya juga distimulir oleh vitamin $\mathrm{B}_{6}$

Aktivitas fagositik (PA) adalah suatu kegiatan selsel fagosit untuk melakukan fagositosis dalam suatu sistem kekebalan non-spesifik, dengan melibatkan sel mononuklier (monosit dan makrofag), granulosit (neutrofil), dan limfosit. Fagosit mempunyai kemampuan intrisik untuk mengikat mikroorganisme secara langsung. Fagositosis yang efektif pada invasi kuman dini akan dapat mencegah timbulnya infeksi. Dalam kerjanya, sel fagosit juga berinteraksi dengan komplemen dan sistem kekebalan spesifik. Monosit ditemukan dalam sirkulasi, tetapi dalam jumlah yang lebih kurang dibanding neutrofil. Sel-sel tersebut bermigrasi ke jaringan dan di sana berdiferensiasi menjadi makrofag yang seterusnya hidup dalam jaringan. Makrofag dapat hidup lama, mempunyai beberapa granul dan melepas berbagai bahan, antara lain lisosim, komplemen, interferon, dan sitokin yang 


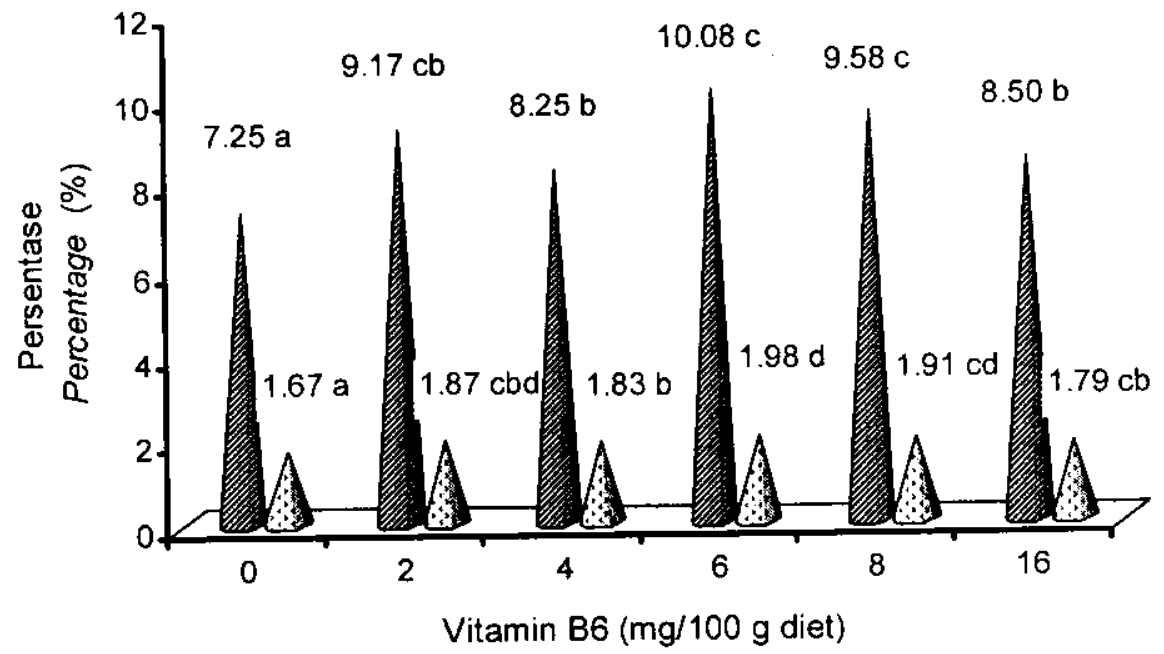

D Aktivitas fagositik (Phagocytic activity) (PA)

Indeks fagositik (Phagocytic index) (PI)

Keterangan (Note):

Setiap nilai yang diikuti dengan huruf yang sama menunjukkan tidak beda nyata $(P>0,05)$

Values in column followed by the same superscripts are not significantly different $(P>0.05)$

Gambar 1. Pengaruh vitamin $B_{6}$ dalam pakan dengan dosis yang berbeda terhadap aktivitas fagositik (PA) dan indeks fagositik (PI) pada benih ikan kerapu bebek, Cromileptes altivelis

Figure 1. Effects of vitamin $B_{6}$ on the phagocytic activity (PA) and phagocytic index $(P I)$ on humpback grouper, Cromileptes altivelis juvenile.

semuanya memberikan kontribusi dalam sistem kekebalan non spesifik dan spesifik (Post, 1987; Tizard, 1988; Stoskopf, 1993; Secombes, 1996; Baratawidjaja, 2002).

Keragaan indeks fagositik ( $\mathrm{Pl}$ ) pada percobaan ini (Gambar 1) terlinat nilai indeks fagositik (PI) tertinggi pada perlakuan vitamin $B_{6}$ dosis $6 \mathrm{mg} / 100 \mathrm{~g}$ pakan (D) sebesar 1,98. Secara statistik perlakuan vitamin $B_{6}$ dibandingkan dengan kontrol berbeda nyata $(P<0,05)$. Nilai antar perlakuan dosis vitamin $B_{6}$ tidak berbeda nyata $(P>0,05)$. PI adalah nilai konstanta dari jumlah total agent yang dihitung dibagi dengan jumlah total sel fagosit. Pada perlakuan vitamin $B_{6}$ dosis 6 $\mathrm{mg} / 100 \mathrm{~g}$ pakan diperoleh nilai $\mathrm{PI}$ sebesar 1,98 yang artinya sel fagosit mampu memfagositosis agent ratarata sebanyak 1,98 . Dalam fagositosis ini adakalanya ditemukan sel fagosit mampu memfagositosis sebanyak 2 sampai 5 agent.

Dari percobaan ini terlihat bahwa peningkatan dosis vitamin $\mathrm{B}_{6}$ berpengaruh terhadap aktivitas fagositik dan indek fagositik. Peningkatan aktivitas fagositik maksimal pada perlakuan dosis vitamin $B_{6}$ sebesar 6 $\mathrm{mg} / 100 \mathrm{~g}$ pakan dan menurun pada dosis vitamin $B_{6}$ $8 \mathrm{mg} / 100 \mathrm{~g}$ pakan. Berdasarkan hasil ini dapat diduga bahwa peningkatan aktivitas fagositik merupakan indikator terhadap peningkatan respon imun non spesifik. Kekebalan terhadap infeksi penyakit dapat dipacu dengan cara vaksinasi, pemberian imunostimulan, vitamin $\mathrm{C}$, dan vitamin $\mathrm{E}$ (Raa et al., 1992). Halver (1989) menyatakan bahwa derivat vitamin B umumnya bekerja sebagai stimulator produksi sel darah yang meliputi eritrosit dan leukosit. Leukosit atau sel darah putih adalah sel yang bertanggung jawab dalam sistem pertahanan tubuh. Leukosit pada ikan terdiri atas neutrofil, monosit, limfosit, dan trombosit. Sebagian besar leukosit ditransfer ke daerah-daerah infeksi untuk memberikan pertahanan yang cepat dan tanggap terhadap setiap gen infeksi (Anderson, 1974; Schalm et al., 1975; Manning \& Tatner, 1985; Brown, 1993; Klontz, 1994).

Johnny et al. (2004) melaporkan bahwa vitamin $B_{6}$ dosis $8 \mathrm{mg} / 100 \mathrm{~g}$ pakan meningkatkan nilai total leukosit pada benih ikan kerapu bebek, Cromileptes altivelis. Pada ikan mas Cyprinus carpio, vitamin $\mathrm{B}_{6}$ dosis $5 \mathrm{mg} / \mathrm{kg}$ pakan dapat meningkatkan nilai total leukosit (Sakthivel \& Sampath, 1989). Pada ikan kakap putih, Wanakowat et al. (1989) melaporkan bahwa vitamin $B_{6}$ juga meningkatkan nilai total leukosit.

Penambahan vitamin $\mathrm{C}$ pada ikan lele dumbo, Clarias sp. antara $500-1.000 \mathrm{mg} / \mathrm{kg}$ pakan mampu mempertahankan sintasan ikan yang dipelihara selama delapan minggu hingga $90 \%$, dan juga meningkatkan respon imun non spesifik (Rukyani et al., 1999). Johnny et al. (2003) melaporkan bahwa pemberian vitamin $\mathrm{C}$ dosis $12 \mathrm{mg} / 100 \mathrm{~g}$ pakan pada benih ikan kerapu macan, Epinephelus fuscoguttatus 


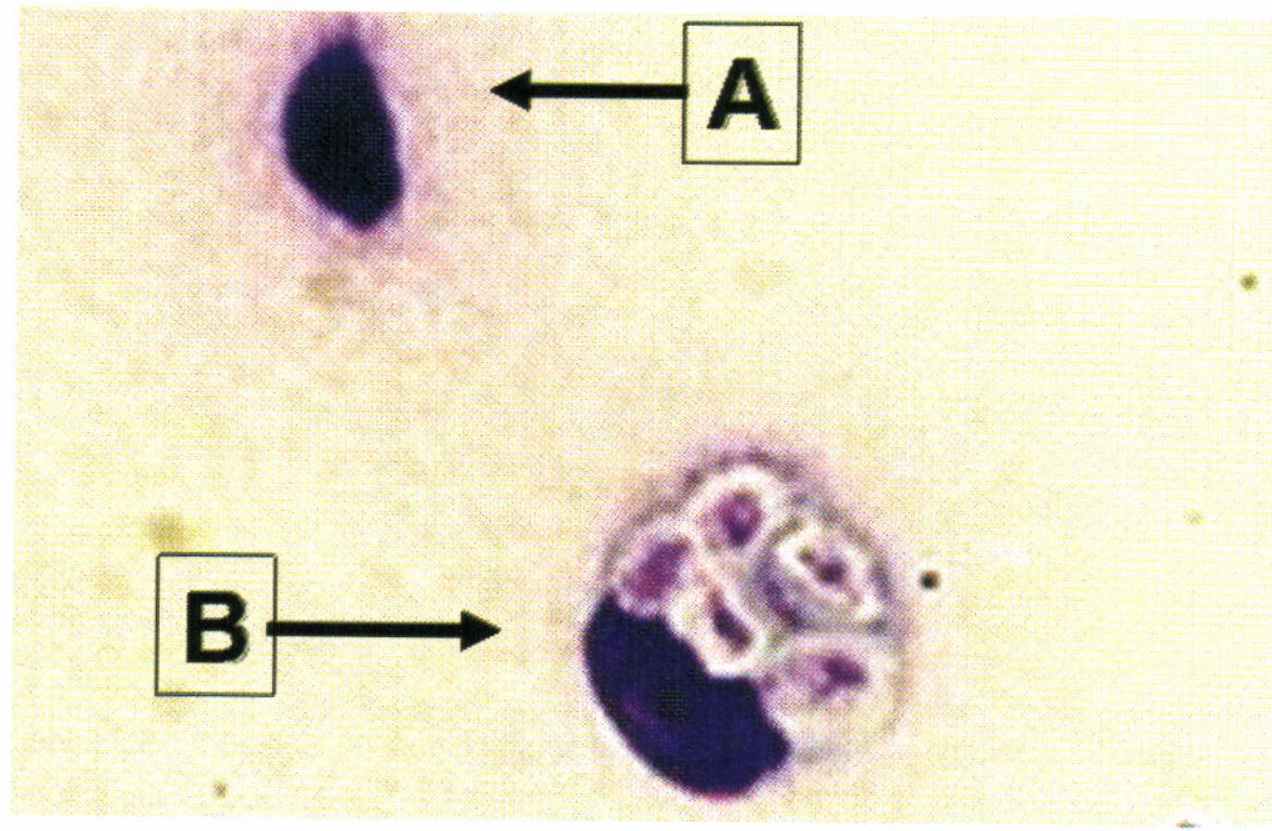

Gambar 2. Peningkatan aktivitas fagositik (PA) pada benih ikan kerapu bebek, Cromileptes altivelis. Sel fagosit yang tidak melakukan fagositosis (A), dan sel fagosit dengan fagositosis (B)

Figure 2. Stimulated of the phagocytic activity (PA) on humpback grouper, Cromileptes altivelis juvenile. Phagocyte cell non phagocytosis (A), and phaghocyte cell on phagocytosis (B)

Keterangan (Note):

Setiap nilai yang diikuti dengan huruf yang sama menunjukkan tidak beda nyata $(P>0,05)$

Values in column followed by the same superscripts are not significantly different $(P>0.05)$

memberikan nilai aktivitas fagositik sebesar $14,67 \%$ dan nilai indeks fagositik sebesar 1,97 . Perlakuan vitamin $\mathrm{B}_{6}$ menunjukkan nilai aktivitas fagositik lebih rendah apabila dibanding dengan perlakuan vitamin $\mathrm{C}$, hal ini sesuai dengan pernyataan Anderson (1996) bahwa vitamin C merupakan suatu bahan stimulator respon imun non spesfik di samping sebagai antioksidan dan stimulator multipel sel. Pada ikan rainbow trout, Oncorrhynchus mykiss kombinasi vitamin $\mathrm{C}$ dan glucan dapat meningkatkan aktivitas fagositik (Verlhac et al., 1998), dan kombinasi vitamin $C$ dan $E$ pada jenis ikan yang sama juga dapat meningkatkan aktivitas fagositik (Wahli et al., 1998).

Pada Gambar 3 terlihat bahwa pengaruh vitamin $\mathrm{B}_{6}$ terhadap keragaan aktivitas lisosim (LA) benih ikan kerapu bebek dosis $6 \mathrm{mg} / 100 \mathrm{~g}$ pakan (D) memberikan nilai LA tertinggi sebesar $1,38 \mathrm{~cm}$ dan secara statistik perlakuan vitamin $\mathrm{B}_{6}$ dibandingkan
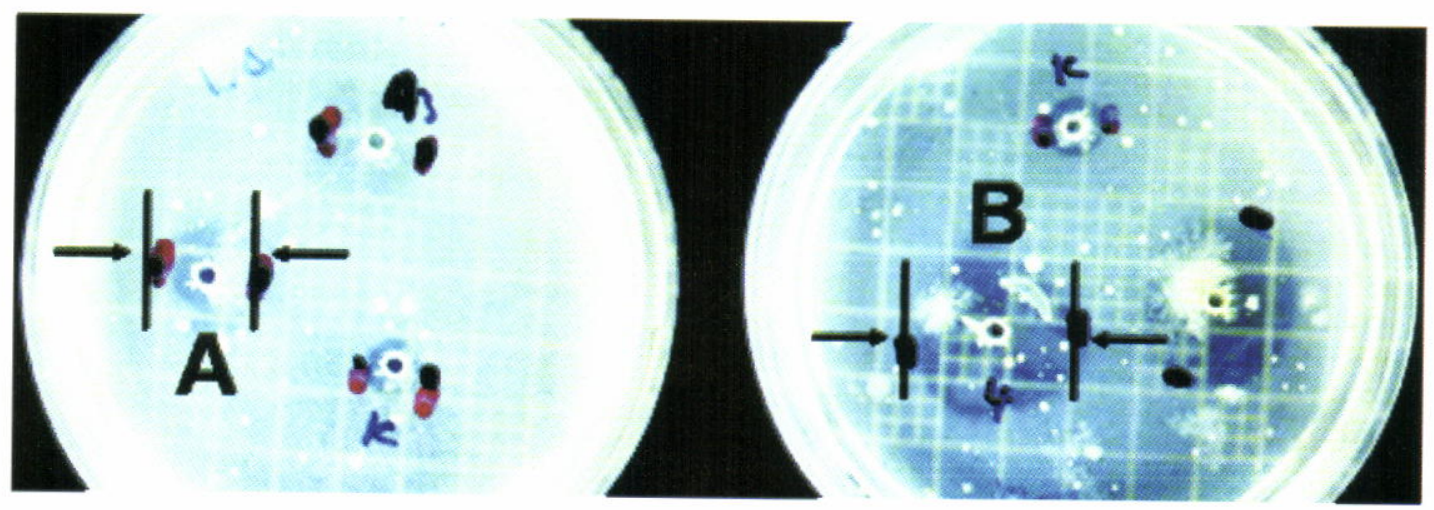

Gambar 3. Pengaruh vitamin $B_{6}$ dalam pakan dengan dosis yang berbeda terhadap aktivitas lisosim (LA) pada benih ikan kerapu bebek, Cromileptes altivelis

Figure 3. Effects of vitamin $B_{6}$ on the lysozyme activity $(L A)$ of humpback grouper, Cromileptes altivelis juvenile 


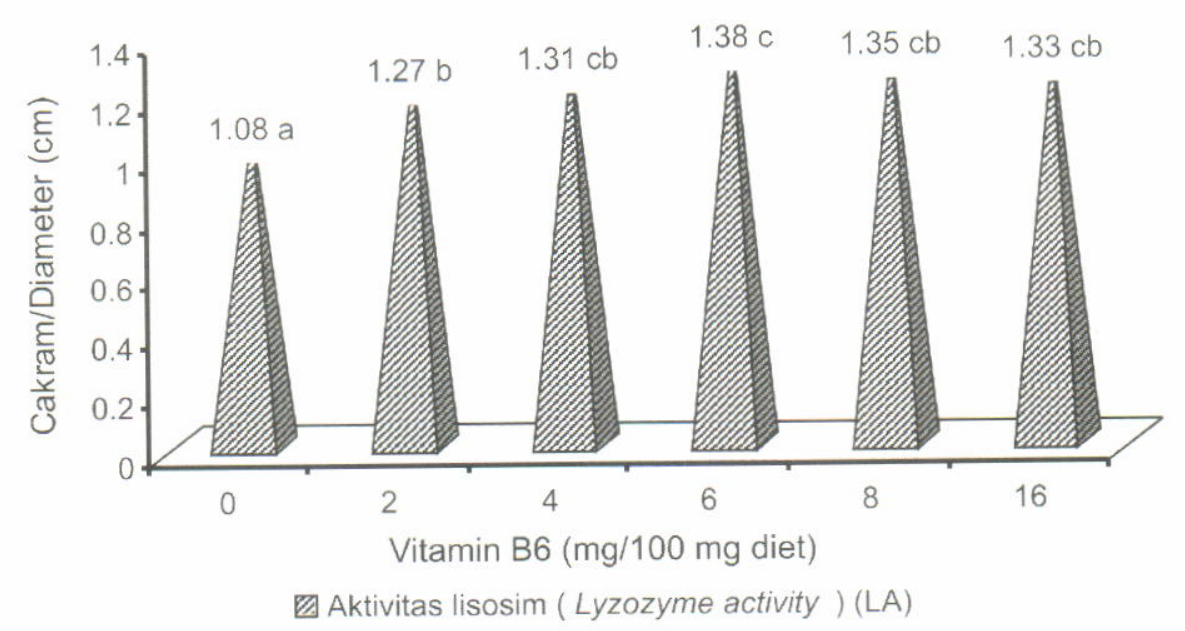

Gambar 4. Peningkatan aktivitas lisosim (LA) pada benih ikan kerapu bebek, Cromileptes altivelis. Aktivitas lisosim pada kontrol (A), dan aktivitas lisosim yang ditingkatkan (B)

Figure 4. Stimulated of the lysozyme activity (LA) on humpback grouper, Cromileptes altivelis juvenile. Lysozyme activity on control (A), lysozyme activity on stimulating (B)

dengan kontrol berbeda nyata $(P<0,05)$. Nilai antar perlakuan dosis vitamin $\mathrm{B}_{6}$ tidak berbeda nyata $(P>0,05)$. Peningkatan dosis vitamin $B_{6}$ memberikan pengaruh terhadap peningkatan aktivitas lisosim. Aktivitas lisosim maksimal terjadi pada perlakuan vita$\min \mathrm{B}_{6}$ dosis $6 \mathrm{mg} / 100 \mathrm{~g}$ pakan, kemudian menurun pada perlakuan vitamin $\mathrm{B}_{6}$ dosis $8 \mathrm{mg} / 100 \mathrm{~g}$ pakan.

Makrofag yang diaktifkan akan melepaskan produk hidrolase seperti lisosim. Lisosim adalah enzim hidrolitik yang ada di dalam lendir, serum, dan sel-sel fagositik dari pelbagai spesies ikan. Kemungkinan zat ini memberikan daya pertahan yang penting terhadap patogen mikrobik. Neutrofil dan monosit dari ikan-ikan mengandung lisosim dalam sitoplasmanya dan lisosim serum mungkin berasal dari leukosit-leukosit tersebut. Lisosim mempunyai aktivitas biologi sebagai mukopeptidase yang menghidrolisa peptidoglikan dinding sel bakteri, hilangnya struktur, dan sel menjadi sensitif terhadap lisis osmotik (Ellis, 1993; Yano, 1996; Baratawidjaja, 2002).

Johnny et al. (2003) melaporkan bahwa perlakuan vitamin $\mathrm{C}$ pada benih ikan kerapu macan dosis 25 $\mathrm{mg} / 100 \mathrm{~g}$ pakan memberikan nilai $2,2 \mathrm{~cm}$ dan terlihat lebih tinggi dari perlakuan vitamin $\mathrm{B}_{6}$. Beberapa laporan lain, pada ikan rainbow trout, Oncorrhynchus mykiss kombinasi vitamin C dan glucan dapat meningkatkan aktivitas lisosim (Verlhac et al., 1998), dan kombinasi vitamin $C$ dan $E$ pada jenis ikan yang sama juga dapat meningkatkan aktivitas lisosim (Wahli et al., 1998).

\section{KESIMPULAN}

Perlakuan vitamin $\mathrm{B}_{6}$ dosis $6 \mathrm{mg} / 100 \mathrm{~g}$ pakan dapat memacu sistem kekebalan pada benih ikan kerapu bebek yang dilambangkan dengan aktivitas fagositik (PA), indeks fagositik (PI), dan aktivitas lisosim (LA).

\section{UCAPAN TERIMA KASIH}

Ucapan terima kasih penulis sampaikan kepada saudara Kasiyanto dan Sumardi teknisi Laboratorium Nutrisi, serta Saudara Putu Suarjana dan Slamet Haryanto teknisi Laboratorium Patologi atas kelancaran penelitian ini.

\section{DAFTAR PUSTAKA}

Anderson, D.P. 1974. Fish Immunology. T.F.H. Publication Inc. Ltd. USA, $239 \mathrm{pp}$.

Anderson, D.P. 1996. Environmental factors in fish health: immunological aspects. (In) The Fish Immune System: Organism, Pathogen and Environment. G. Iwama and T. Nakanishi (eds.), Academic Press. USA, p. 289-310.

Andrew, C., A. Exell, and N. Carrington. 1988. The Manual of Fish Health. Salamander Books Ltd. United Kingdom, 208 pp.

Baratawidjaja, K.G. 2002. Imunologi Dasar Edisi Kelima. Balai Penerbit FK-UI. Jakarta, 457 pp.

Brown, L. 1993. Aquaculture for Veterinarians: Fish husbandary and Medicine. Pergamon Press Ltd. USA, $447 \mathrm{pp}$.

Ellis, A.E. 1993. Lysozyme assays. In Stolen et al. (Eds.). Techniques in Fish Immunology-1. Sos Publications, Fair Haven, NJ 07760. USA, p. 101-103.

Halver, J.E. 1989. The Vitamin (In) Halver, J.E. (Eds.) Fish Nutrition; Second Edition. Academic Press, Inc. San Diego, California, p. 32-101.

Johnny, F. I.N.A. Giri, K. Suwirya, dan D. Roza. 2003. Pengaruh vitamin $C$ dalam pakan terhadap keragaan respon imun non-spesifik benih ikan kerapu macan, 
Epinephelus fuscoguttatus. Laporan Hasil Penelitian $B B R P B L$ Gondol, 12 pp.

Johnny, F., I N.A. Giri, K. Suwirya, dan D. Roza. 2004. Pengaruh vitamin $B_{6}$ dalam pakan terhadap keragaan hemositologi benih ikan kerapu bebek, Cromileptes altivelis. Laporan Hasil Penelitian BBRPBL Gondol, $15 \mathrm{pp}$.

Klontz, G.W. 1994. Fish Hematology. In Stolen et al. (Eds.). Techniques in Fish Immunology-3. Sos Publications, Fair Haven, NJ 07704-3303. USA, p. 121-131.

Manning, M.J. and M.F. Tatner. 1985. Fish Immunology. Academic Press Inc. London, 369 pp.

Murray, R.K., D.K. Granner, F.A. Mayes, and V.W. Rodwell. 1997. Biokimia Harper. Terjemahan Hartono (Eds.). Penerbit Buku Kedokteran. Jakarta, p. $623-625$.

Post, G. 1987. Texbook of Fish Health. T.F.H. Publications Inc. USA, $288 \mathrm{pp}$.

Raa, J., G. Roerstad, R. Engstad, and B. Robertsen. 1992. The use of immunostimulants to increase resistence of aquatic organisms to microbial infections $(/ n)$ Shariff, M., R.P. Subangsihe and J.R. Arthur (Eds.) Disease in Aquaculture /. Fish Health Section Asian Fisheries Society. Manila. Phillipines, p. 39-50.

Rowley, A.F. 1993. Collection, separation and identification of fish leukocytes. In Stolen et al. (Eds.). Techniques in Fish Immunology-1. Sos Publications, Fair Haven, NJ 07760. USA, p. 113-136.

Rukyani, A., A. Sunarto, dan Taukhid. 1999. Pengaruh pemberian imunostimulan dan penambahan vitamin C pada ransom pakan terhadap peningkatan daya tahan tubuh ikan lele dumbo, Clanias sp. J. Penel. Perik. Indonesia, 5(4): 30-36.

Sakthivel, M. and K. Sampath. 1989. Dietary requirement of pyridoxine for Cyprinus carpio based on haematological studies. J. Aqua. Trop, (4): 125135.

Secombes, C.J. 1996. The Nonspecific Immune System: Cellular Defenses. D.P. 1996. (In) The Fish Immune System: Organism, Pathogen and Environment. G.
Iwama and T. Nakanishi (Eds.), Academic Press. USA, p. 63-105.

Schubert, G. 1987. Fish Diseases a Complete Introduction. T.F.H. Publications Inc. USA, $125 \mathrm{pp}$.

Schaim, O.W., N.C. Jain, and E.J. Carroll. 1975. Veterinary Hematology. $3^{\text {rd }}$ Edition. Lea \& Fehiger. Philadelphia, $807 \mathrm{pp}$.

Siwicki, A.K. and D.P. Anderson. 1993. Immunostimulation in Fish; Measures the effects of stimulants by serological and immunological methods, International Workshop and Training Course in Poland, $15 \mathrm{pp}$.

Shiau, S.Y. and H.L. Hsieh. 1997. Vitamin $B_{6}$ requirements of tilapia Oreochromis niloticus $\times 0$. aureus fed two dietary protein concentrations. Fisheries Science, 63(6): 1,002-1,007.

Stoskopf, M.K. 1993. Fish Medicine. W.B. Saunders Company. Mexico, $664 \mathrm{pp}$

Tizard, 1. 1988. Pengantar Immunologi Veteriner. Terjemahan Partodiredjo et al. 1988. Airlangga University Press, $497 \mathrm{pp}$.

Wahli, T., V. Verlhac, J. Gabaudan, W. Schuep, and W. Meler. 1998. Influence of combined vitamins $C$ and $E$ on non-specific immunity and disease resistance of rainbow trout, Oncorhynchus mykiss (Walbaum). J. Fish Disease. 21: 127-137.

Wanakowat, J., M. Boonyaratpalin, T. Pimoljinda, and M. Assavaare. 1989. Vitamin $B_{6}$ requirement of juvenile Seabass, Lates calcarifer. Takeda \& Watanabe (Eds.) Proc. Thind int. Symp. on Feeding and Nutr. in Fish. Toba Aug. 28-Sept. 1, Japan, 1989, p. 141-147.

Verlhac, V., A. Obach, J. Gabaudan, W. Schuep, and R. Hole. 1998. Immunomodulation by dietary vitamin C and gluca in rainbow trout (Oncorhynchus mykiss). Fish \& Shellfish Immunology, 8: 409-424.

Yano, T. 1996. The nonspecific immune system: Humoral defense Anderson, D.P. 1996. (In) The Fish Immune System: Organism, Pathogen and Environment. G. Iwama and T. Nakanishi (Eds.), Academic Press. USA, p. 106-159. 
